\title{
Analysis of role performance and effectiveness of dairy extension service providers in Karnataka State
}

\author{
Somasekaran Subash, Girish V, MCA Devi and Muniandy Sivaram
}

Received: 24 September 2021 / Accepted: 29 September 2021 / Published online: 21 December 2021

(C) Indian Dairy Association (India) 2021

\begin{abstract}
Dairy extension services delivery system providing access to services and critical inputs plays a cardinal role in adoption of technologies by the farmers for improved livestock productivity. In a pluralistic environment, multiple dairy extension service providers extend various services and inputs to the dairy farmers. In this context, the present study was undertaken to assess the role performance of various dairy extension service providers and their effectiveness in Karnataka State. A total of 400 dairy farmers who were availing the services from different extension service providers were selected as respondents for the study using multi-stage random sampling method. The Department of Animal Husbandry and Veterinary Services (DAH\&VS) of the State played a predominant role in providing 'breeding services' (87.25\% A.I \& 90 P.D), 'preventive services' (vaccination $86 \%$, deworming $89 \%$, and $76 \%$ disease surveillance) and 'curative services' (82\%). Whereas, the Dairy Co-operative Societies (DCS) played a vital role in extending assured 'marketing services' (94\%), 'input services' (fodder seeds $86.50 \%$ and feed supplements $89.25 \%$ ), 'implementation of dairy development schemes' $(86 \%)$ and provision of 'extension advisory and training services' $(84.50 \%)$. The effectiveness of service providers as perceived by the dairy farmers as per the weighted mean score indicates that DAH\&VS was found more effective in extending 'health care services' (278.67) and 'breeding and reproduction
\end{abstract}

Southern Regional Station, ICAR- National Dairy Research Institute, Bengaluru-560030, Karnataka, India

Somasekaran Subash $(\bowtie)$

Southern Regional Station, ICAR- National Dairy Research Institute, Bengaluru-560030, Karnataka, India

E-mail: subashagri@gmail.com services' (274.26), whereas, DCS were more effective in extending assured 'marketing services' (289.73), providing 'input support services' (278.33), 'implementation dairy development schemes' (274.53) and provision of 'extension advisory and training services' (264.35). The present study concludes that most of the dairy extension service providers played a significant role in extending different dairy extension services and inputs to the farmers. However, concerted efforts need to be made by all the stakeholders for possible convergence among them in reaching out the dairy farmers and providing emphasis on 'dairy extension education services' in addition to 'providing inputs and support services' to the dairy farmers.

Keywords: Animal Husbandry and Veterinary Department, Dairy Farmers, Dairy Extension, Dairy Co-operatives

\section{Introduction}

The Indian dairying is characterized as 'production by masses' rather than 'mass production'. Dairy extension services delivery system providing the services and critical inputs which are important to the adoption of technologies by the farmers for improving livestock productivity. The primary dairy extension service providers in Karnataka State are Department of Animal Husbandry and Veterinary Service (DAH\&VS), Dairy Cooperative Societies (DCS) of Karnataka Co-operative Milk Producers Federation Ltd (KMF), National Agricultural Research and Education System (NARES) institutions, Non-Governmental Organizations (NGO's) and Private Input agencies/Dairies. The dairy extension delivery systems are expected to addresses three important requirements of farmers which includes; technical services, critical inputs and education and advisory services. It is evident from the existing situation at grassroots level where our extension system primarily focused on first two requirements and whereas, the 'education and advisory services' are grossly neglected (Rao and Natchimuthu, 2015). Due to this lacuna, most of the livestock producers being small and marginal farmers, their capacity to overcome the present challenges and to adopt the latest technologies developed by research institutions is limited. Absence of effective extension machinery for this purpose further adds problem. Though each of the institute has different mandate and approaches in reaching out the farmers, most of the time, its 
efforts were sporadic in nature and lack of collaboration among these different organizations poses a serious hindrance for the development of livestock sector.

Though there are many stakeholders involved, in reality they focused mainly on provision of 'health care and breeding related services', while 'livestock/dairy education' receives the tertiary importance. Further, the livestock/veterinary extension system focus on "dairy production" to certain extent, whereas "dairy processing" aspects of extension services were grossly neglected (Subash et al. 2014). Therefore, efficient delivery of dairy extension services has become a matter of great concern and hence, there is a need to understand the role performance of current dairy extension delivery system and to assess their effectiveness in delivering services to farmers. Thus an attempt was made to assess the role performance of various dairy extension service providers in Karnataka State.

\section{Materials and Methods}

The present study was conducted in Karnataka State during the period 2019-2020. Based on the physiographic profile of the State, Karnataka was divided into four regions namely, North Zone, South Zone, Central Zone and Coastal \& Malnad Zone and from each Zone two Districts (progressive and less progressive districts based on bovine density and milk production density as on 2019) was selected purposively. The selected districts for the study were Belagavi and Gadag from Northern region, Bangalore Rural and Chamarajanagar from Southern region, Davanagere and Chitradurga from Central region Udupi and Uttara Kannada from Coastal and Malnad region representing progressive and less progressive dairy development districts. For the selection of dairy farmers, a multistage stratified random sampling plan was adopted and accordingly from each of the eight districts two Taluks were selected through random sampling method. From each Taluk (cluster of villages) twenty five dairy farmer-respondents were selected randomly thus constituting a total of 400 dairy farmer as respondents for the study. The data were collected by personal interview method using pretested semi-structured interview schedule.

The role performance of various dairy extension service providers existed in the study area, for the purpose of the studying their activities, it was grouped under seven broad categories viz., 'breeding and reproduction services', 'preventive services', 'curative services', 'extension advisory and training services', 'dairy schemes implementation' and 'marketing services'. The primary data pertaining to the different services availed by the respondents in the recent past from various dairy extension service providers was presented and discussed by each service provider. The overall effectiveness the services provided by various service providers was ascertained in terms of 'regularity' in providing services, 'quality', 'timeliness' of the services provided and 'cost effectiveness'. Weighted score for each dairy service delivery was calculated by assigning scores on a three point continuum and then multiplying the percent of observation by the respective score and finally adding the total observation. The weighted mean score was calculated by dividing the sum of total scores for all the indicators of a particular system by the total number of indicators for the particular service and were used for ranking different service providers.

\section{Results and Discussion}

\section{Role Performed by Department of Animal Husbandry and Veterinary Services (DAH\&VS)}

From the table 1, it is evident that breeding and reproduction services was predominantly provided by DAH\&VS as perceived by large majority of the dairy farmers who had availed 'Artificial Insemination (A.I)'(87.25\%) and 'Pregnancy Diagnosis (P.D) services' $(90 \%)$ for their milch animals. Similar observation was seen in the findings of Mahalakshmi \& Devi (2016) and Karthikeyan et al. (2018) in availing breeding services. In the case of 'preventive services', majority of the dairy farmers availed 'vaccination services' (86\%), 'deworming services' (89\%) and 76 percent of the respondents opined that the department conducted 'periodic disease surveillance'. Further, majority of them availed the services of 'treatment' $(82 \%)$ and 'surgery' $(72.25 \%)$ for their dairy animals from the DAH\&VS. With regard to the services pertaining to 'inputs distribution', significant percent of the respondents availed 'veterinary medicines' (87\%), 'fodder seeds and stem cuttings' (74\%), 'feed supplements'(37\%) and other inputs like 'mineral mixtures', 'rubber mats'/'chaff cutter' (29.50\%) from the DAH\&VS. In the case of provision of 'extension advisory and training services' by the DAH\&VS, a significant percentage of the respondents received 'technical guidance on dairy farming' (66.50\%), 'organized farmers meeting/demonstrations/field days and visits to exhibitions' (31.25\%), 'organized animal health cum infertility camps' (69\%), 'organized trainings programmes'(24\%), 'farm literature preparation and distribution' (47.25\%). Nearly half of the respondents opined DAH\&VS involved in implementation of different 'dairy development schemes' (44.50\%) and 'provided guidance about credit and insurance facilities' (36.50\%). The DAH\&VS had played an important role in extending 'breeding and reproduction and health care services' to the farmers in the study area. This might be due to the fact that the mandate of DAH \& VS is to provide 'breeding and reproduction and health care services' which were essential and easily accessible to the farmers from the Veterinary hospitals and dispensaries situated in their locality. Similar findings were reported by Umali et al. (1992), Ravikumar \& Chander, (2011) and Yadav et.al. (2017) who also observed overwhelming support from public sector in providing breeding and clinical veterinary services.

Role Performed by Dairy Co-operative Societies (DCS) of Karnataka Co-operative Milk Producers Federation Ltd (KMF) 
From the results presented in table 1 , it is clear that DCS provided access to large majority of the dairy farmer-members to avail the assured 'marketing services'(94\%), 'provided technical inputs' viz., veterinary medicines ( $30 \%)$, fodder seeds and stem cuttings (86.50\%), feed supplements $(89.25 \%)$ and other inputs like mineral mixtures, rubber mats/chaff cutter $(53.25 \%)$. With respect to provision of 'extension advisory and training services' by the DCS, a significant percentage of the respondents received 'technical guidance on dairy farming' $(84.50 \%)$, 'organized farmers meeting/demonstrations/field days and visits to exhibitions' (45.00\%), 'organized animal health cum infertility camps' $(87.50 \%)$, 'organized trainings programmes'(58.50\%), 'farm literature preparation and distribution' (69\%). Karthikeyan et al. (2018) and Rathod et al. (2012) also reported that majority of the farmers availed advisory services from dairy co-operatives. A large majority of the member-respondents opined DCS were involved in 'implementation of dairy development schemes' (86\%) and provided 'guidance about credit and insurance facilities' $(74 \%)$. Most of the respondents availed the benefits under Ksheeradhara (milk incentives for milk pourers @ Rs.5/lit of milk poured) programme which is successfully implemented by KMF. Further, a significant per cent (74\%) of respondents 'received assistance in availing credit' from nationalized banks/ cooperative banks and insurance facilities where 70 percent of the premium was borne by the State Government and KMF. The DCS had played an important role in extending assured 'marketing services', 'distribution of technical inputs' followed by provision of 'breeding and reproduction and health care' services to the farmers in the study area. This might be due to the fact that Karnataka Co-operative Milk Producers Federation Ltd being a producer company has important role in 'procurement of milk' and 'distribution of subsidized inputs and services' to the member-dairy farmers. Similar findings were observed by Rathod et al. (2012) who were also observed that cooperatives have a significant role in production and marketing activities. A significant majority of the respondents availed 'breeding services viz, 'Artificial Insemination' (79\%) and 'Pregnancy Diagnosis' (68\%) from Dairy cooperatives. Similar findings were reported by Rathod et al. (2012) that DCS were involved in providing breeding services. Further the dairy cooperatives also played a significant role in assisting DAH\&VS in conducting vaccination $(51 \%)$, deworming (58.50) and periodic disease surveillance (31.75\%) programmes and dairy cooperatives also extended the services of 'animal treatment' (80\%) and 'surgical procedures' $(46.50 \%)$ as expressed by majority of respondents. Similar findings were reported by Singodia (2018) that significant percentage of farmers availed preventive $(80.35 \%)$ and curative services $(71.42 \%)$ from dairy cooperatives.

\section{Role Performed by NARES (National Agricultural Research and Education System) Institutions}

The NARES system comprised of KVK's and Research Institutions of ICAR/SAUs/SUV which played a significant role in providing training and technical guidance to the dairy farmers as well as for the field extension functionaries in the study area. It is evident from table. 1 that NARES institutions played a significant role in provision of 'extension advisory and training services' which included 'technical guidance on dairy farming' (44.50\%), 'organized farmers meeting/demonstrations/field days and visits to exhibitions' $(62.50 \%)$,' 'organized animal health cum infertility camps' (18.50\%), 'organized trainings programmes'(48\%), 'farm literature preparation and distribution' (52\%). Similar findings were reported by Meena et al. (2019). Further, these institutions were also involved in distribution of inputs viz., 'veterinary medicines' (30\%), 'fodder seeds and stem cuttings' (35\%), 'feed supplements' (27\%) and other inputs like 'mineral mixtures' and 'rubber mats/chaff cutter' (21.50\%). The researchers observed that NARES institutions had played a significant however a limited role in reaching out to the dairy farmers through organizing training programmes as well as field extension oriented activities covering the limited geographical area. Further, NARES institutions were primarily involved in capacity development of field extension functionaries through organizing various 'trainers' training programme' on recent advancements in dairying.

\section{Role Performed by NGOs (Non-Governmental Organizations)}

The NGOs working in study area were found involved in extending various extension services and provision of inputs to the dairy farmers. Majority of the dairy farmers expressed that NGOs were involved in extending 'breeding and reproduction services' viz., 'Artificial Insemination' (40.50\%) and 'Pregnancy Diagnosis' $(19.50 \%)$ followed by distribution of inputs, 'veterinary medicine' (19\%), 'fodder seeds and stem cuttings' (31\%), 'feed supplements' (44.25\%) and other inputs like 'mineral mixtures', 'rubber mats/chaff cutter' (26.50\%). Further, they were also involved in providing 'extension advisory and training services' like, 'technical guidance on dairy farming' (24\%), 'organized farmers meeting/demonstrations/field days and visits to exhibitions' $(31.50 \%)$, 'organized animal health cum infertility camps' (13\%) and 'organized trainings programmes' $(16.50 \%)$. The role of NGOs were seen in assisting the dairy farmers in availing the breeding services and also in facilitating them in availing credit services from the organized credit institutions.

\section{Role Performed by Private Consultants}

The private veterinarians as consultant/practioners predominantly involved in provided 'breeding and reproduction and 'health care treatment services' to the dairy farmers at their door steps. However, those services were availed by the farmers only during the emergency situations when they were unable to take their cattle to nearest dispensary due to the severity of illness of the animals and other reasons. However the services of private consultants were cost intensive compared to the other governmental agencies and hence their services were used 
occasionally. From the table 1 it could be observed that only one fourth of the respondents (A.I $31.50 \%$ and P.D 33.50\%) availed 'breeding services and reproduction' and 'healthcare services'(Treatment $49 \%$ and surgery $28 \%$ ) from private consultants since adequate breeding and health care services were provided by DAH\&VS and DCS in the study area. This finding are in contrary with the findings of Karthikeyan et al. (2018) which revealed that the large majority of respondents

Table 1 Role performance of different service providers in dairy extension delivery system $(n=400)$

\begin{tabular}{|c|c|c|c|c|c|c|c|}
\hline Sl.No. & $\begin{array}{l}\text { Role profile of } \\
\text { service providers }\end{array}$ & DAH\&VS & $\begin{array}{l}\text { Dairy Co- } \\
\text { operatives }\end{array}$ & NARES & NGO's & $\begin{array}{l}\text { Private } \\
\text { consultants }\end{array}$ & $\begin{array}{c}\text { Private input } \\
\text { dealers/ } \\
\text { Private dairies }\end{array}$ \\
\hline \multicolumn{8}{|c|}{ I Breeding services } \\
\hline 1. & AI services & $349(87.25)$ & $316(79.00)$ & $0(0.00)$ & $162(40.50)$ & $126(31.50)$ & $18(4.50)$ \\
\hline 2. & Pregnancy diagnosis & $360(90.00)$ & $272(68.00)$ & $0(0.00)$ & $78(19.50)$ & $134(33.50)$ & $15(3.75)$ \\
\hline \multicolumn{8}{|c|}{ II Preventive services } \\
\hline 1. & $\begin{array}{l}\text { Vaccination } \\
\text { programmes }\end{array}$ & $344(86.00)$ & $204(51.00)$ & $0(0.00)$ & $0(0.00)$ & $0(0.00)$ & $0(0.00)$ \\
\hline 2. & Deworming & $356(89.00)$ & $234(58.50)$ & $0(0.00)$ & $0(0.00)$ & $0(0.00)$ & $0(0.00)$ \\
\hline 3. & $\begin{array}{l}\text { Periodic disease } \\
\text { surveillance }\end{array}$ & $304(76.00)$ & $127(31.75)$ & $0(0.00)$ & $0(0.00)$ & $0(0.00)$ & $0(0.00)$ \\
\hline \multicolumn{8}{|c|}{ III Curative services } \\
\hline 1. & $\begin{array}{l}\text { Treatment to } \\
\text { animals }\end{array}$ & $328(82.00)$ & $320(80.00)$ & $137(34.25)$ & $0(0.00)$ & 196(49.00) & $0(0.00)$ \\
\hline 2. & Performing surgery & $289(72.25)$ & $186(46.50)$ & $0(0.00)$ & $0(0.00)$ & $112(28.00)$ & $0(0.00)$ \\
\hline \multicolumn{8}{|c|}{ IV Input services } \\
\hline 1. & $\begin{array}{l}\text { Veterinary } \\
\text { medicines }\end{array}$ & $348(87.00)$ & $120(30.00)$ & $120(30.00)$ & $76(19.00)$ & $142(35.50)$ & $272(68.00)$ \\
\hline 2. & Fodder seeds & $296(74.00)$ & $346(86.50)$ & $140(35.00)$ & $124(31.00)$ & $0(0.00)$ & $246(61.50)$ \\
\hline 3. & Feed supplements & $148(37.00)$ & $357(89.25)$ & $108(27.00)$ & $177(44.25)$ & $0(0.00)$ & $296(74.00)$ \\
\hline 4. & Other inputs & $118(29.50)$ & $213(53.25)$ & $86(21.50)$ & $106(26.50)$ & $0(0.00)$ & $184(46.00)$ \\
\hline \multicolumn{8}{|c|}{ V Extension advisory and training services } \\
\hline 1. & $\begin{array}{l}\text { Providing technical } \\
\text { guidance to farmers } \\
\text { on various aspects of } \\
\text { dairying }\end{array}$ & $266(66.50)$ & $338(84.50)$ & $178(44.50)$ & $96(24.00)$ & $240(60.00)$ & $228(57.00)$ \\
\hline 2. & $\begin{array}{l}\text { Organizing farmers } \\
\text { meeting/demonstration } \\
\text { days and visits to exh }\end{array}$ & $\begin{array}{l}125(31.25) \\
\text { ns /field } \\
\text { iibitions }\end{array}$ & $180(45.00)$ & $250(62.50)$ & $126(31.50)$ & $0(0.00)$ & $0(0.00)$ \\
\hline 3. & $\begin{array}{l}\text { Organizing cattle } \\
\text { health cum infertility ca }\end{array}$ & $\begin{array}{l}276(69.00) \\
\text { amps }\end{array}$ & $350(87.50)$ & $74(18.50)$ & $52(13.00)$ & $0(0.00)$ & $0(0.00)$ \\
\hline 4. & $\begin{array}{l}\text { Organizing training } \\
\text { programmes for farmer }\end{array}$ & $96(24.00)$ & $234(58.50)$ & 192(48.00) & $66(16.50)$ & $0(0.00)$ & $0(0.00)$ \\
\hline 5. & $\begin{array}{l}\text { Farm literature } \\
\text { preparation and distrib }\end{array}$ & $\begin{array}{l}189(47.25) \\
\text { bution }\end{array}$ & $276(69.00)$ & $208(52.00)$ & $0(0.00)$ & $0(0.00)$ & $0(0.00)$ \\
\hline \multicolumn{8}{|c|}{ VI Dairy schemes implementation } \\
\hline 1. & $\begin{array}{l}\text { Identifying } \\
\text { beneficiaries and imple } \\
\text { dairy development sch }\end{array}$ & $\begin{array}{l}178(44.50) \\
\text { ementation } \\
\text { hemes }\end{array}$ & $344(86.00)$ & $0(0.00)$ & $0(0.00)$ & $0(0.00)$ & $0(0.00)$ \\
\hline 2. & $\begin{array}{l}\text { Providing guidance } \\
\text { to avail credit\& insurar }\end{array}$ & $\begin{array}{c}146(36.50) \\
\text { nce facilities }\end{array}$ & $296(74.00)$ & $0(0.00)$ & $0(0.00)$ & $0(0.00)$ & $0(0.00)$ \\
\hline \multicolumn{8}{|c|}{ VII Marketing services } \\
\hline 1. & $\begin{array}{l}\text { Procurement of } \\
\text { milk, storage } \\
\text { facility and }\end{array}$ & $0(0.00)$ & $376(94.00)$ & $0(0.00)$ & $0(0.00)$ & $0(0.00)$ & $150(37.50)$ \\
\hline
\end{tabular}




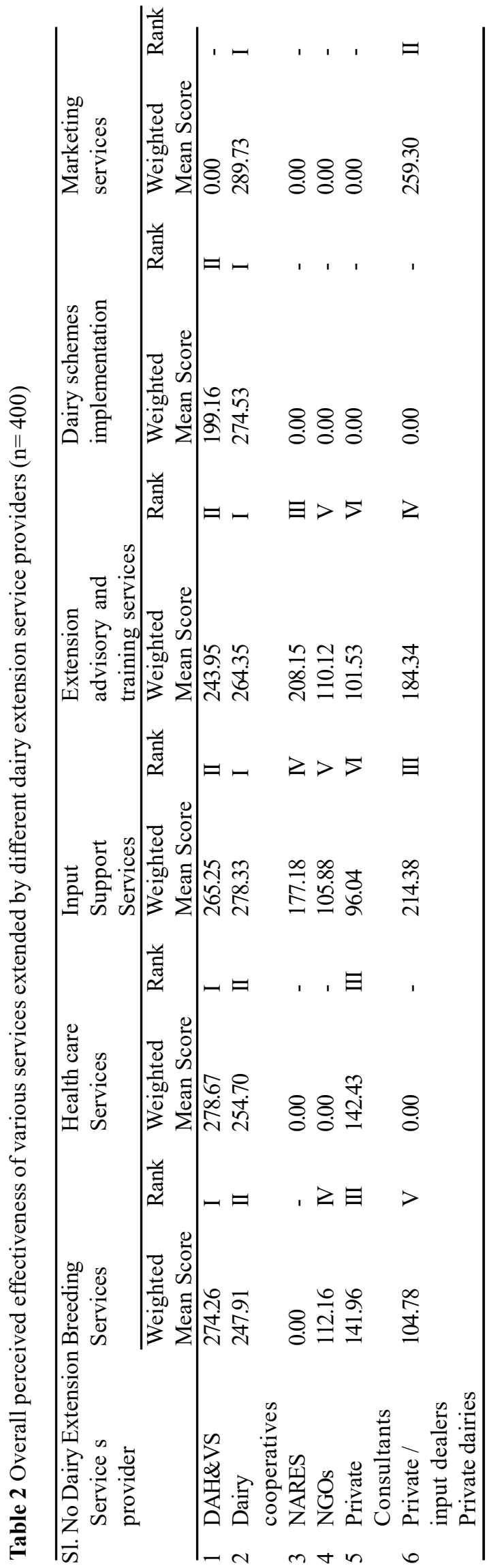

(81.81\%) availed health care services offered by the private integrators. Further, they were also found involved in provding veterinary medicines $(35.50 \%)$ at their door steps and providing technical guidance farmers on various aspects of dairying $(60 \%)$. The role of private practitioners were largely limited to provision of breeding and reproduction and health related services, supply of veterinary medicines and providing need based technical guidance to the farmers in the study area.

\section{Role Performed by Private Input Dealers/Dairies}

Many private input dealers were found operating in the study area and extending timely delivery of input services to the farmers. It could be observed from table. 1 that a significant percent of respondents availed 'veterinary medicines' $(68 \%)$, 'fodder seeds/ root slips/ stem cuttings' (61.50\%), 'feed supplements' (74\%) and 'other inputs' $(46 \%)$ from the different input dealers accessible in their locality. In addition to this, private dairies were found playing a significant role in 'procurement of milk', as significant percent of respondents $(37.50 \%)$ preferred and availed 'marketing services' from private dairies as their payment dues were made comparatively earlier than the dairy cooperative societies. Further, they were also involved in provision of 'extension advisory and training services' (57\%) and a small percent of the respondents also availed breeding services.

\section{Overall Perceived Effectiveness of Various Services extended by Different Dairy Extension Service Providers}

The overall perceived effectiveness of the dairy service providers were studied based on weighted mean score. From the Table 2 it is evident that with the highest weighted mean score, DAH\&VS was ranked first and effective in providing 'health care services' (278.67) and 'breeding and reproduction services' (274.26) and second in 'input support services' (265.26), 'Extension advisory and training services' (243.95) and 'implementation dairy development schemes' (199.16). This may be due to the fact that DAH\&VS is mandated in extending health care and breeding and reproduction related services to the dairy farmers on a regular basis with free of cost which makes it more effective. The services of dairy cooperatives was perceived effective and ranked first in providing 'marketing services' (289.73), 'input support services' (278.33), 'dairy schemes implementation' (274.53) and 'extension, advisory and training services' (264.35). Since major role of dairy cooperatives is to provide assured market and remunerative price for the milk produced by the farmer members of the co-operative societies and to provide subsidized input services and extension advisory services the DCS was perceived effective in extending the input and marketing services. Similar findings were also reported by Karthikeyan et al. (2019). The other stakeholders of the dairy extension delivery system, with a limited mandate of extending the services and inputs to the dairy farmers viz., NARES institutions were found more effective in providing 'extension advisory services' (208.15), NGOs in 'breeding services' (112.16), 
Private consultants in 'breeding and health care services' (142.43) and private input dealers and dairies in providing 'marketing services' (259.30) and 'input support services' (214.38), respectively.

\section{Conclusions}

The DAH\&VS of the State played a predominant role in providing breeding and reproduction services and health care services. Whereas, the dairy co-operatives played a vital role in providing assured marketing services, input support services, implementation of dairy schemes and provision of extension advisory and training services to the dairy farmers in the study area. The results of the study clearly indicates that DAH\&VS and DCS are two major dairy extension service providers in the study area and were found effective in delivering their services as perceived by the majority of the dairy farmers. However, the services of other service providers viz, NARES institutions, NGOs, Private Consultants and Private input agencies and Dairies were found in extending their limited services to the dairy farmers as per their mandates. However concerted efforts are to be made by all the stakeholders for possible convergence among them in reaching out the dairy farmers and providing emphasis on 'Dairy Extension Education Services' in addition to 'Providing Critical Inputs and other Support Services' to the dairy farmers. Hence, the present study concludes that most of the dairy extension service providers played a significant role in extending different dairy extension services and inputs to the dairy farmers with a different mandate and approaches in reaching out the farmers, most of the time, their efforts were overlapping with other service providers, sporadic in nature and lack of collaboration among these different organizations poses a serious hindrance for the development of dairy sector.

\section{Acknowledgements}

The authors thankfully acknowledge ICAR-National Dairy Research Institute for extending all necessary support in conducting this study.

\section{References}

Karthikeyan S, Arunmozhi M C, Narmatha, N, Uma V (2018) Perception of dairy farmers regarding effectiveness of artificial insemination services of different dairy service delivery systems. Indian J Anim Hlth 57: 27-34

Karthikeyan S, Devi MCA, Narmatha N, Uma V, Thirunavukkarasu D (2019) Perceived Effectiveness of Dairy Service Delivery Systems in Namakkal District of Tamil Nadu. Indian J of Ext Edu 55: 53-59

Mahalakshmi S, Devi M C A,Kiran, R (2016) Socio Personal Profile of Resource Poor Dairy Farmers and Constraints in Dairying. Res J of Anim Husb \& Dairy Sci 7: 91-95

Meena M, Kale R, Singh S, and Singh A (2019) LEAD Farmer Based F2F Extension Mode 1: Role of Krishi Vigyan Kendras and Technology Adoption Determinants for Enhancing Model's Effectiveness. J of Agri Sear 6:199-204

Rao S V N, Natchimuthu K (2015) Inefficient Extension Services: Livestock Owners Bear the Brunt. AESA Blog No.45. Retrieved from https://www.aesanetwork.org/ wpcontent/uploads/2016/03/ AESA-BLOG-45.pdf Accessed 12 June 2020

Rathod P, Nikam T R, Landge S, Hatey A (2012) Perceived Constraints in Livestock Service Delivery by Dairy Cooperatives: A case study of Western Maharashtra. Indian J Dairy Sci 65: 423-430

Ravikumar R K, and Chander M (2011) Livestock Extension Education Activities of the State Departments of Animal Husbandry (SDAH) in India: A case of Tamil Nadu State. Indian J of Anim Sci 81:757762

Singodia M, Rewani S K, Rajoria S, Singh V, Ram G (2018) Perception of Livestock Farmers towards Existing Livestock Service Delivery Systems in Jaipur District of Rajasthan, India. Int J of Livest Res 9:111-119

Subash S, Devi, M C A, Dixit P K (2014) Dairy Extension Services: Critical Issues and Strategies. Indian Dairyman 66: 174-177.

Umali D, Feder G, De Haan, C (1992) The Balance between Public and Private Sector Activities in the Delivery of Livestock Services. World Bank Discussion Papers \#1 No.63, Washington, D.C., U.S.A.

Yadav J, Tripathi H, Balaraju B L, Yadav R (2017). Constraints in Availing the Livestock Extension Services under State Department of Animal Husbandry as Perceived by Women Livestock Farmers. Indian J of Ext Edu 53: 51-53 